(C) S.V. Alferov

\title{
VOICING THE MOVE: DISCURSIVE PRACTICES OF SCOTTISH DANCE INSTRUCTION
}

\begin{abstract}
Bridging dance anthropology and multimodal discourse analysis, the article focuses on language used to teach and/or describe various versions of the pas de basque step in Highland, Scottish country, Scottish step and "called" Ceilidh dancing of Scotland. It analyses pedagogic discourse observed during on-and offline classes and dance events across the globe alongside the author's own embodied experience as a Scottish dancer, learner and teacher.

When examining culturally and somatically contextualised uses of English in Scottish dance pedagogy, the article takes into account a range of dance manuals and instructions published between 1950 and 2020 by the Royal Scottish Country Dance Society, the Royal Scottish Official Board of Highland Dancing, the United Kingdom Alliance of Professional Teachers of Dancing and other organisations and individuals.

Revisiting issues of communicating (and delegating) authority, (re)shaping the dance tradition(s) and providing/refraining from regulation, the study is aimed at helping to better appreciate the mutual interconnectedness between pedagogic discourse, on the one hand, and dance learning and teaching as an embodied social and cultural experience, on the other.
\end{abstract}

Keywords: pedagogic discourse, dance instruction, teacher-student power relations, traditional dance, Scottish country dancing, Highland dancing, ethnolinguistics, ethnochoreology, dance phenomenology

For Citation: Alferov, S.V. 2021. Voicing the move: discursive practices of scottish dance instruction. Herald of Anthropology (Vestnik Antropologii) 2: 177-197.

\section{Introduction}

"Dance tends to be a craft taught by experts." This comment was made by Rod Downey, an experienced Scottish country dance (SCD) teacher and dance deviser from New Zealand, responding to a questionnaire devoted to printed and digital materials which may be used in class when teaching the pas de basque step (Alferov 2019a). In the context of Scottish dancing it evokes the days of "dancies" - 18th-early-20th-century dancing masters who started shaping the repertoire of what is now known as various distinct Scottish dance styles: Highland, SCD and Scottish step dancing (Melin 2018: 2).

Alferov, Sergey V. - UKA Fellow, Head teacher, Shady Glen Scottish \& Welsh dance studio (127051 Moscow, Russia, Bolshoy Karetny per., 2). E-mail: scotstepdance@gmail.com ORCID: https:// orcid.org/0000-0002-2393-0812 
Identifying a skilled and knowledgeable dance teacher as "the main source of ideas", Downey seems to redistribute power and authority in dance teaching and learning. He thus goes beyond the standardisation of dance style(s) and technique brought about in mid20th century by the Royal Scottish Country Dance Society (RSCDS), the Royal Scottish Official Board of Highland Dancing (RSOBHD) and other organisations (Ballantine 2016). Indeed, an autonomous "expert" teacher may be regarded as a somewhat redundant figure by the regulatory bodies, each set to become "one generally recognised authority" / "a representative board of control" (SOBHD 1968: xv) aimed, in the case of the RSCDS, at "the discovery and re-introduction of old traditional standards of technique and performance" while combating "riot and licence" (Milligan 1956: 106).

Although samples of regulatory discourse presented in textbooks or dance manuals lend themselves easily to "Foucauldian" critical examination as evidence of how "disciplinary power employs the norm to correct behaviour and transform individuals into docile bodies" (Havis 2014: 111), the main purpose of this article is somewhat different.

Rather than analysing the "commentary" discourse recontextualising the contemporary social practices (Van Leeuwen 2008: 12-17) of SCD, Highland, soft-shoe step and called Ceilidh dancing, I intend to look at how pedagogic discourse (i.e. language used "for the purposes of the initiation of others" - Christie 2002: 24 following Bernstein 1990) may reflect and/or impact dance teaching and learning. Examining "how human beings employ language to build the social and cultural worlds" we inhabit (Goodwin, Duranti 1992: 2) will hopefully facilitate understanding of "power relations" (Foucault 1994: 223) in a situation of embodied learning and/or practising dance. In particular, looking at how different variations of pas de basque (pronounced /pa: do 'ba:sk/ or /pa di 'ba/), a step used in all styles of traditional Scottish dancing, are taught on- and offline, I am going to address the following questions:

1. To what extent do features of pedagogic discourse highlight similarities and/or differences between the ways distinct styles of Scottish dancing are being taught and/or practised? (Q1)

2. How significant is the role of action verbs, especially in the imperative (e.g., "Jump!"), in teaching Scottish dance movements? (Q2)

3. How pronounced is the connection between pedagogic discourse witnessed in Scottish dance learning environments and the teacher-student power relations? (Q3)

\section{"A rhythmic little verse": dancing words as rhythmic clues and aide-memoire}

June 2020. A young adult dancer from Wellington, New Zealand, is practising some solo Scottish steps at home following an online tutorial created by Diana Hastie, a teacher based in Sydney, Australia. The teacher says (Scot Step 2020):

Sample 1

\begin{tabular}{c|c|c|c|c}
\hline The words: & We begin & with a very slow & pas de basque & to the right \\
\hline $\begin{array}{c}\text { Accompanying } \\
\text { movements of the } \\
\text { teacher's body: }\end{array}$ & $\begin{array}{c}\text { Body erect, feet } \\
\text { in first position } \\
\text { (Scot Step } \\
2013 \mathrm{a})\end{array}$ & $\begin{array}{c}\text { Left hand points to } \\
\text { the left (the viewers' } \\
\text { right) }\end{array}$ & $\begin{array}{c}\text { Left hand moves } \\
\text { rhythmically still } \\
\text { pointed sideways. }\end{array}$ & $\begin{array}{c}\text { Left hand } \\
\text { goes back to } \\
\text { the original } \\
\text { "akimbo" } \\
\text { position. }\end{array}$ \\
\hline
\end{tabular}




\begin{tabular}{c|c|c|c|c}
\hline The words: & So spring & beat & beat & and shake... \\
\hline $\begin{array}{c}\text { Accompanying } \\
\text { movements of } \\
\text { the teacher's } \\
\text { body: }\end{array}$ & $\begin{array}{c}\text { The teacher } \\
\text { marks what she } \\
\text { says: steps to the } \\
\text { viewer's right... }\end{array}$ & $\begin{array}{c}\text {.."beats" (makes a } \\
\text { soft step) with the } \\
\text { front foot in third } \\
\text { position... }\end{array}$ & $\begin{array}{c}\text {...beats" with } \\
\text { the rear foot... }\end{array}$ & $\begin{array}{c}\text {.. and makes two } \\
\text { "shake" actions } \\
\text { with her right foot } \\
\text { (no hop). }\end{array}$ \\
\hline
\end{tabular}

"Dancing words" (in bold) accompany the demonstration of the step and each movement in particular. I underline the prominent syllables, i.e. those carrying the tonic stress (Roach 2009: 153) and thus emphasised "by the speaker in order to highlight the intended meaning" (Underhill 2005: 69). To mark the soft pas de basque step (see Picture 1), the teacher uses a standard RSCDS formula "spring beat beat" (RSCDS 2019, RSCDS 2011: 5.4.2, Knight 2000: 40, RSCDS 1999) also applicable to a lot of soft-shoe Scottish step repertoire (RSCDS 2013: 89, NWSD 2005: 92).

As the tutorial continues, the teacher modifies the "dancing words":

The sequence is repeated with the same wording as in sample 2 starting on the learner's left foot, with the teacher mirroring and chanting the words. When the step is practised to the music (fiddle+piano+whistle), the teacher sings the words along during the first half of the step. The second half starts with a loudly whispered /pa:/. Then the teacher stops speaking but continues dancing, thus creating a "syntactic-bodily gestalt" (Keevallik

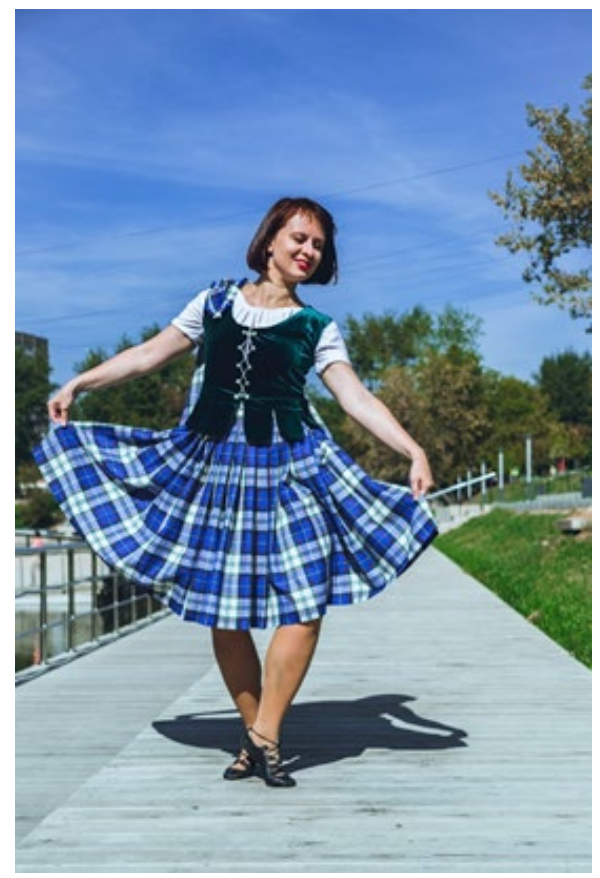

Pic. 1. A Scottish step dancer finishing a soft pas de basque. Moscow, August 2018. Photo by V. Lee 2015: 322), i.e. intertwining verbalised instructions and movements of the body, with both being subordinated to the rhythm and the tempo of the music (Keevallik 2013: 351, 365).

Sample 2

\begin{tabular}{l|l|l|l|l}
\hline The words: & Pas /p a:/ & de /ds:/ & basque & and shake... \\
\hline $\begin{array}{l}\text { Accompanying } \\
\text { movements of } \\
\text { the teacher's } \\
\text { body: }\end{array}$ & $\begin{array}{l}\text { The teacher springs } \\
\text { fmakes a soft jump } \\
\text { frome foot to the } \\
\text { right... }\end{array}$ & $\begin{array}{l}\ldots \text { "beats" we front foot in } \\
\text { the viewer's } \\
\text { third position... }\end{array}$ & $\begin{array}{l}\ldots \text { with the rear } \\
\text { foot... }\end{array}$ & $\begin{array}{l}\text { "shake" } \\
\text { with her right foot } \\
\text { (no hop). }\end{array}$ \\
\hline
\end{tabular}

As for the learner, she shares her experiences with the teacher in a Facebook comment: "Diana, even when you're not actually coaching, I hear your voice." The teacher comments that this is "just how it should be" (SCD Teachers 2020). According to Helen Russell, an expert Scottish step and SCD teacher from Scotland and RSCDS Chairman (2016-2018), a dance teacher's voice is one of the most important tools "at your disposal for conveying 
dance and musicality to the dancers" and giving them "rhythmic clues" (Scot Step 2019).

My experience of learning and teaching Scottish step dancing (especially since I started learning from Scottish teachers in 2006) corresponds well to this vision. I frequently sing the dancing words "in my head" (SCD Teachers 2020) or aloud. These rhythmical chants can help me and my learners experience a sensation of flow (Shernoff, Csikszentmihalyi 2009) when dancers, while fully concentrated, no longer explicitly direct/control every little movement. Instead, we develop and/or follow certain automated habits, with the teacher's almost hypnotic rhymes leading them into the accepted ("correct") rhythm and helping internalise steps on a somatic level.

Spring 2020 (and earlier). Primary dancers (aged 4-6, predominantly girls) in the counties of Windsor and Essex, Ontario, Canada, are practising at home what they have learnt in class (in a studio or via Zoom) from their Highland dance teachers, Kodi Cunningham (Miss Kodi) and Allison Smith (Miss Allison). Some of them use a Youtube tutorial prepared by their teachers, with Miss Allison demonstrating 16 "pas de bas" (a routine typically performed by primary dancers at RSOBHD competitions around the world) and Miss Kodi reciting the following verse over bagpipe music (Pride of Scotland School of Dance 2018):

Sample 3

\begin{tabular}{c|c|c|c|c}
\hline The words: & This is & $\begin{array}{c}\text { the Sword } \\
\text { dance! }\end{array}$ & Just watch & me prance! \\
\hline $\begin{array}{c}\text { Movements of the } \\
\text { body: }\end{array}$ & \multicolumn{4}{|c}{ Miss Allison stands with feet and arms in first position } \\
\hline $\begin{array}{c}\text { Bars of music } \\
\text { (introduction) }\end{array}$ & 1 (counts 1,2) & 2 (counts 3,4) & 3 (counts 5,6) & 4 (counts 7, 8) \\
\hline
\end{tabular}

\begin{tabular}{l|l|l|l|l}
\hline The words: & Bow down & Up top! & Ready or not & I'll show you off! \\
\hline $\begin{array}{l}\text { Movements of } \\
\text { the body: }\end{array}$ & $\begin{array}{l}\text { Miss Allison } \\
\text { bows down. }\end{array}$ & $\begin{array}{l}\text { Miss Allison } \\
\text { straighten s } \\
\text { back up. }\end{array}$ & $\begin{array}{l}\text { Miss Allison steps to } \\
\text { her left (not mirroring } \\
\text { the move) }\end{array}$ & $\begin{array}{l}\text { Miss Allison points } \\
\text { her right toe in third } \\
\text { position and pauses. }\end{array}$ \\
\hline $\begin{array}{l}\text { Bars of music } \\
\text { (introduction) }\end{array}$ & 5 & 6 & 7 (counts 5,6) \\
(counts 1,2) & (counts 3, 4) & 8 (counts 7, 8) \\
\hline
\end{tabular}

\begin{tabular}{c|c|c|c|c}
\hline The words: & One beat & Two beat & Three beat & Four beat... \\
\hline Movements of the body: & \multicolumn{4}{|c}{ Miss Allison dances a series of "two-beat" pas de bas(que). } \\
\hline Bars of music (the step) & 1 (counts 1,2) & 2 (counts 3, 4) & 3 (counts 5, 6) & 4 (counts 7, 8) \\
\hline
\end{tabular}


Targeted at younger dancers, the verse helps highlight the rhythm of the dancing routine (including the bow) in a creative way that would appeal to learners, who wish their dancing to be recognised and appreciated ("Just watch me prance!"). The language is subordinated to the rhythm (cf. Keevallik 2013: 351): function words (e.g., "is", "just" or "off") are prominent if they fall onto a strong beat (count) of the music. Unlike Diana Hastie, Kodi Cunningham is not singing along. She uses her voice to focus the learners' attention on the rhythm, not on the melody, thus emphasising the "steady pulse and a strong steady beat" of the recorded music, which is crucial for competitive Highland dancers in Scotland and overseas (Ballantine 2016: 184-185).

As a Highland dancer and Highland dance teacher, I also tend to focus on the rhythm, not the melody, when supporting my own dancing or that of my learners with verbal rhythmical cues. As I started Highland dancing in my late teens and have mainly taught adult dancers, I have never used (or been taught using) a verse similar to the one

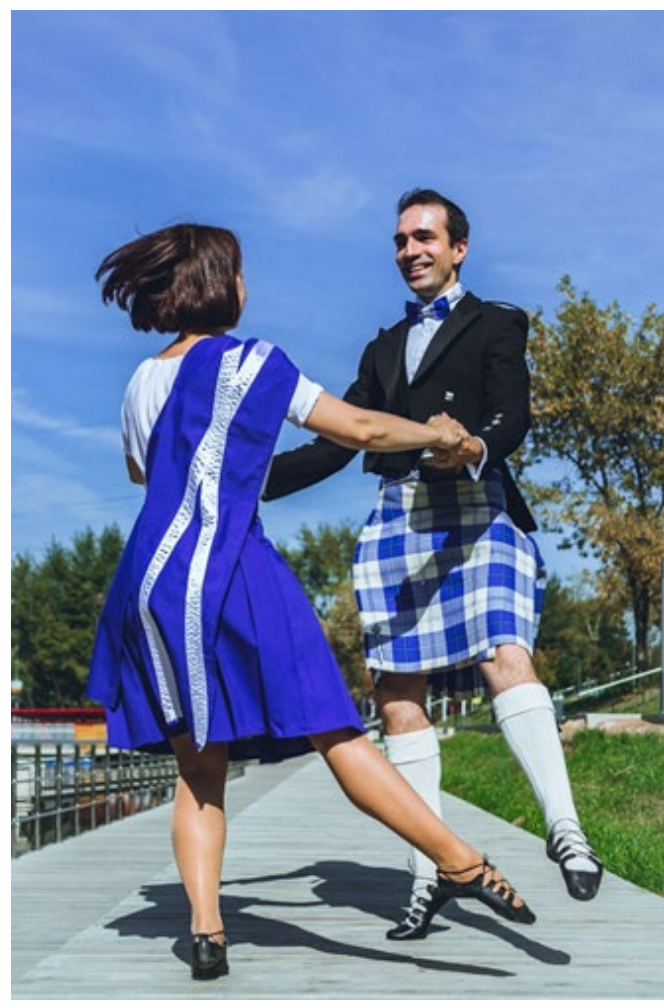

Pic. 2. An extension (pointed toe of the working foot) at the end of an SCD pas de basque. Moscow, August 2018. Photo by V. Lee. in Sample 3. Rather, for the two-beat pas de bas(que), I have heard (and used) the words "together beat" corresponding to the counts "1\& a 2" (BBC 1996b, Perreault 2020).

April 2020. Members of the RSCDS Edinburgh Branch (Scotland) and SCD enthusiasts from all over the world (men and women of different age, with no upper age limit) are practising the three-beat pas de basque watching an online tutorial by Elizabeth Harry from the safety of their homes (RSCDS Edinburgh 2020). Talking about adding an extension (jeté) in fourth (intermediate) aerial position, the teacher says:

Sample 4

\begin{tabular}{c|c|c|c|c}
\hline The words: & $\begin{array}{c}\text { And that allows } \\
\text { you then }\end{array}$ & to spring & back onto it. & Spring beat beat (x3) \\
\hline $\begin{array}{c}\text { Accompanying } \\
\text { movements of } \\
\text { the teacher's } \\
\text { body: }\end{array}$ & $\begin{array}{c}\text { The right foot is } \\
\text { moving from the } \\
\text { fourth intermediate } \\
\text { aerial position } \\
\text { towards the floor... }\end{array}$ & $\begin{array}{c}\text {...to land } \\
\text { on the } \\
\text { floor on } \\
\text { "spring". }\end{array}$ & $\begin{array}{c}\text { The teacher } \\
\text { completes the } \\
\text { "beat out" part } \\
\text { of the pas de } \\
\text { basque. }\end{array}$ & $\begin{array}{c}\text { The teacher marks the } \\
\text { step as she counts, with } \\
\text { minimal or no elevation } \\
\text { between each "spring". }\end{array}$ \\
\hline
\end{tabular}


Elizabeth Harry uses the "spring beat beat" formula when practising to music, modifying the dancing words to "spring beat point" after having introduced the extension. The recorded music she uses starts with a pre-recorded rhythmical "Ready and..." simulating what a teacher would say in a class with a live musician. The dancing words are there to develop the core rhythm of the step and remind the key elements each pas de basque consists of. "Spring beat point" outlines what each pas de basque should look like (see Pic. 2).

December 2019. Fortingall villagers and visitors of this charming $19^{\text {th }}$-century village in the Highlands of Scotland are dancing Britannia Two Step, a simple dance for groups of three in a circle, at a called Ceilidh dancing event in the Fortingall Village Hall. As the Gallivanters Ceilidh Band plays the tune, a dance caller's job is to remind the dancers what to do (Cowing 2019):

Sample 5

\begin{tabular}{|c|c|c|c|c|}
\hline The words: & Pas de bas out & pas de bas in & twirl & \\
\hline $\begin{array}{l}\text { Movements of the } \\
\text { dancers: }\end{array}$ & \multicolumn{4}{|c|}{$\begin{array}{c}\text { Older participants step beat or step beat beat generally rhythmically from side } \\
\text { to side (no turnout or clear foot positions). Younger participants try to repeat } \\
\text { the steps sideways, but are less rhythmical. }\end{array}$} \\
\hline Bars of music & 1 (counts 1,2$)$ & $2($ counts 3,4$)$ & $3($ counts 5,6$)$ & $4($ counts 7,8$)$ \\
\hline The words: & Forward two & three kick & back two & three stop. \\
\hline $\begin{array}{l}\text { Movements of the } \\
\text { dancers: }\end{array}$ & \multicolumn{4}{|c|}{$\begin{array}{l}\text { All the participants walk forward ( } 3 \text { steps), kick forward with their right foot } \\
\text { and walk backwards (three steps), some more rhythmically than others. }\end{array}$} \\
\hline Bars of music & $5($ counts 1,2$)$ & $6($ counts 3,4$)$ & $7($ counts 5,6$)$ & $8($ counts 7,8$)$ \\
\hline
\end{tabular}

As called Ceilidh dancing is aimed at encouraging everyone to participate, the rhythm of the pas de basque is not clearly pronounced in the "dancing words". Footwork only matters as long as dancers do not bump into each other too much, hence highlighting "in" and "out" (meaning into and out of the circle of dancers). Unlike "forward two three kick", where every strong beat in the music is marked by a discourse stress, the only prominent syllable in the /'padiba/ is the first one. The dancers move accordingly, with a considerable variation in their interpretation of the rhythm and the moves that comprise the step. Some do step touch, some jump and kick, some barely have the time to step sideways and then move back etc.

As the caller's instructions are there to remind the dancers what to do, some Ceilidh callers give the reminders in advance, anticipating the move (Cutting Edge Band 2017): 


\begin{tabular}{c|c|c|c|c}
\hline The words: & & Two pas de bas! & Go! \\
\hline $\begin{array}{c}\text { Movements of } \\
\text { the dancers: }\end{array}$ & $\begin{array}{r}\text { Dancers in groups of } 6 \text { are moving in a circle to their right, possibly getting } \\
\text { ready to the next part of the dance, the Dashing White Sergeant. }\end{array}$ \\
\hline Bars of music & 5 (counts 1,2) & 6 (counts 3,4) & 7 (counts 5,6) & 8 (counts 7,8) \\
\hline
\end{tabular}

As a Ceilidh dance caller, I tend to combine both approaches, announcing the upcoming formation or movement just before it is about to start and/or verbalising some shorter moves rhythmically, so that less experienced dancers get additional rhythmical support as they dance at a public or private function (e.g., a wedding or a Scottish-themed festival/ gathering).

Examining samples 1-6 in their sociocultural contexts demonstrates that the "dancing words" are widely used across the spectrum of dancing styles and traditions that can be labelled "Scottish". Rhythmical formulas vary depending on the teacher's (or dance caller's) background and the core targets they are used to achieve, as summarised in Table 1:

Table 1

\begin{tabular}{|c|c|c|c|c|}
\hline The target (T): & SCD & $\begin{array}{l}\text { Highland } \\
\text { dancing }\end{array}$ & $\begin{array}{l}\text { Scottish step } \\
\text { dancing }\end{array}$ & $\begin{array}{l}\text { Ceilidh } \\
\text { dancing }\end{array}$ \\
\hline $\begin{array}{l}\text { T1: Remind the } \\
\text { dancers the se- } \\
\text { quence they need to } \\
\text { follow }\end{array}$ & $\begin{array}{l}\text { Relevant (the word } \\
\text { "set" is used to } \\
\text { achieve this, refer- } \\
\text { ring to a sequence of } \\
\text { two pas de basque in } \\
\text { a country dance) }\end{array}$ & $\begin{array}{l}\text { Highly rele- } \\
\text { vant }\end{array}$ & Highly relevant & $\begin{array}{l}\text { Highly } \\
\text { relevant }\end{array}$ \\
\hline $\begin{array}{l}\text { T2: Support the } \\
\text { dancers' rhythm }\end{array}$ & Relevant & $\begin{array}{l}\text { Highly rele- } \\
\text { vant }\end{array}$ & Highly relevant & $\begin{array}{c}\text { Not relevant } \\
\text { for the pas de } \\
\text { basque }\end{array}$ \\
\hline $\begin{array}{l}\text { T3: Develop the } \\
\text { dancers' musicality }\end{array}$ & $\begin{array}{l}\text { Theoretically rele- } \\
\text { vant }\end{array}$ & $\begin{array}{l}\text { Possibly rele- } \\
\text { vant (mainly } \\
\text { due to the } \\
\text { rhythm) }\end{array}$ & Highly relevant & $\begin{array}{c}\text { Not necessari- } \\
\text { ly relevant }\end{array}$ \\
\hline $\begin{array}{l}\text { T4: Introduce the key } \\
\text { elements of the step } \\
\text { when teaching it }\end{array}$ & Highly relevant & Relevant & $\begin{array}{l}\text { Relevant but } \\
\text { possibly over- } \\
\text { looked (pas } \\
\text { de basque is } \\
\text { assumed known) }\end{array}$ & Not relevant \\
\hline
\end{tabular}

Given that targets T1-T4 may be relevant for a wide range of dancing styles far beyond the Scottish tradition (cf. Keevallik 2013, 2015 on the pedagogic discourse in lindie hop dancing), the differences between Scottish styles of dance as highlighted by the way they embed "dancing words" into their practice look more pronounced than the similarities between them. 
Indeed, even the very term pas de basque can mean different things to different stakeholders. When you hear the /sk/ at the end of it, you can assume the speaker has some RSCDS training and/or is a foreigner (non-Scot). When the last element is pronounced / ba:/ or /ba/, you may sometimes wrongly assume the speaker comes from a Highland dancing background, whereas in fact (s)he is a frequent Ceilidh-goer for whom the term refers to a combination of a jump and a kick or a step and a beat or almost anything else. In fact, this is the way many young Highland dancers in Scotland interpret and perform the "pas de bas" in Ceilidh dances like the Dashing White Sergeant or Britannia Two Step. For them, "pas de bas" in the Highland repertoire is all about precision, rhythm and control. When Ceilidh dancing, however, they are happy to embrace the "riot and licence" the RSCDS used to be determined to combat back in the 1920s - 1960s.

$* * *$

Summing up, it is possible to answer Q1 above as follows: rhythmical "dancing words" as a key element of pedagogic discourse present in all the styles of Scottish dancing examined in this article, help highlight some similarities and points of departure between these dancing traditions. When examined within its cultural setting(s) in Scotland and across the globe, the language of Scottish dancing calls into question the very existence of "Scottish dancing" as a meaningful whole. Rather, one can observe a range of practices and traditions that share some common roots, overlap but exist and develop in their own distinctive ways, increasingly isolated from one another (cf. Alferov 2019b: 173-175).

\section{Dance instruction versus dance description: the role of mode}

If "perception is always interdependent with action" (Smith 2012: 137), it is essential to understand what action is implied and/or called for in three main types of instructional input: written textbook instructions, step/dance descriptions and teacher/dance caller talk. I propose doing that combining discourse analysis with elements of dance phenomenology, so that "the things that give the dance and its experience their distinctiveness are brought to reflective awareness" (Pakes 2011: 34).

As a Highland dance teacher, I feel it is my responsibility to double-check the main points and nuances of technique with the latest edition of the RSOBHD textbook available. My colleagues worldwide either use the same source or, alternatively, consult the New Zealand Academy of Highland and National Dancing Syllabus. Some teachers in Scotland may also be using the SOHDA textbook instead (cf. Scott 2005: 318-322).

To exemplify how overwhelmed a reader of the RSOBHD (SOBHD 2019) textbook can be, I suggest comparing the description of the pas de basque with that of an early-mid-20 ${ }^{\text {th }}$-century dancing master and choreographer D.G. MacLennan (1952).

Count 2 of the pas de basque in Highland dancing

Sample 7

\begin{tabular}{|c|c|}
\hline MacLennan 1952: 46 & (R)SOBHD 2019:17 \\
\hline $\begin{array}{c}\text { [...] beat or stamp lightly Right on spot, } \\
\text { while gently bearing weight on left toe } \\
\text { (Count 2). }\end{array}$ & $\begin{array}{c}{[\ldots] \text { then beat the ball of the other foot in third or fifth }} \\
\text { rear position at the same time sharply extending the } \\
\text { front foot, if required, to begin the next movement. }\end{array}$ \\
\hline
\end{tabular}


The whole of MacLennan's basic description of the pas de basque has 55 words arranged in four sentences (five lines of text). The RSOBHD version has 65 words and is one long sentence (four lines of text), which makes it significantly harder to follow. I have to reread the latter minimum twice every time I see it and still have a feeling there is some hidden meaning that eludes me.

To instruct the reader, MacLennan uses seven verbs in the imperative, some accompanied by adverbs ("stand", "spring", "fully extend", "rest", "smartly bring", "beat or stamp lightly") and two present participles ("loosening right foot" and "gently bearing"). When reading the text, I feel as if an expert teacher is gently guiding me. As I try to follow the instructions, additional questions emerge: When exactly do we extend? How can I bring the foot in "smartly"? Can we lower the heel when resting "flat"? A teacher would be able to answer these, but the book cannot.

The RSOBHD book uses two imperatives (spring, beat), four present participles (preparing, bringing, placing, sharply extending) and one infinitive expressing a possible purpose ("to begin"). For me, this creates an immediate physical tension as if I have to control ten thousand things at the same time, and all of them are equally important. It is impossible to mark (let alone dance) the step while reading due to the density of the text, which sounds prescriptive rather than instructive. So while reading I focus on the requirements such as the height of positions ("second aerial low"!) and the timing of extensions (at the same time as the back beat). Note 4 (only added in the $8^{\text {th }}$ edition) clarifies the height of the back beat, which is very helpful.

In general, the RSOBHD textbook reads like a legal text, with rules set out and (at least some) possible "loopholes" closed. This makes it a useful reference, but a daunting read. Actual work on Highland dancing technique in a classroom with an enthusiastic and qualified teacher is a much more energising experience. Using more direct imperatives thus makes the explanation "dancer-friendly" and easy to follow. On the other hand, shorter instructions, with adverbs of manner (e.g., "lightly", "smartly") used more frequently, leave more room for multiple interpretations and potential misunderstanding.

To make these observations more embodied by using the researcher's body "as a site of scholarly awareness" (Spry 2001: 706), I will provide two phenomenologyinformed accounts of my practising two different steps from the Sword dance, one of the core dances within the Highland dancing repertoire (Picture 3). These are the reverse points step (SOBHD 2019: 35) and

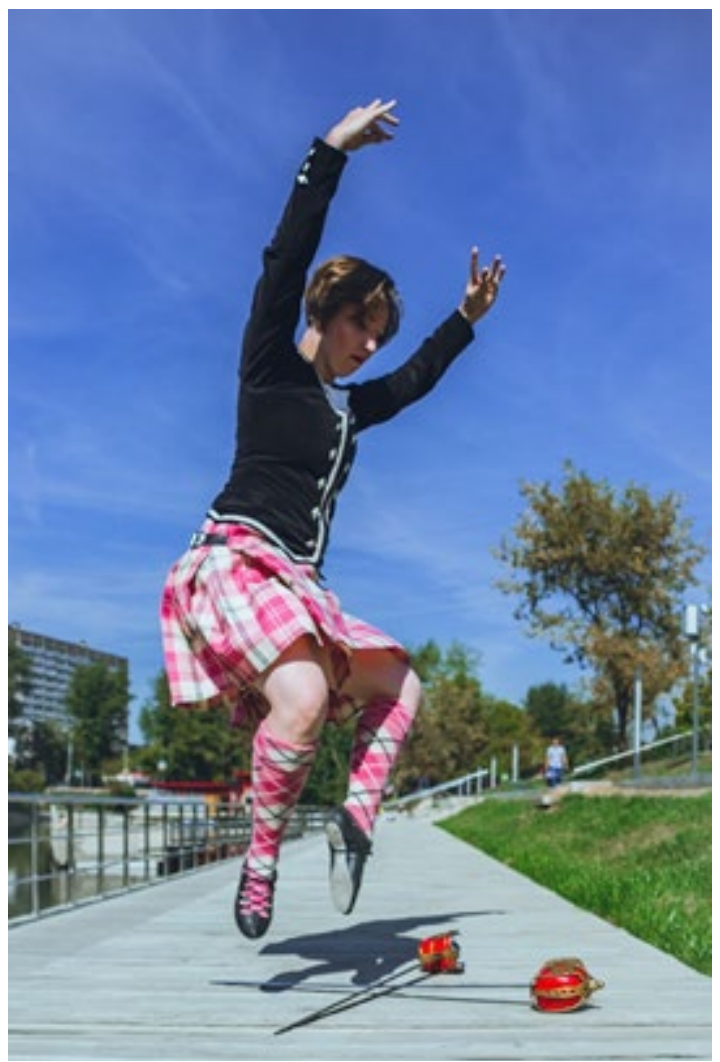

Pic. 3. Open pas de basque over a crossed pair of Highland broadswords. Moscow, August 2018. Photo by V. Lee. 
an alternative pas de basque step from the SOBHD Old Steps Folder (SOBHD 2009), the latter not danced at official RSOBHD competitions.

$* * *$

With the RSOBHD textbook open in my left hand, I am reading and marking the reverse points step. Unlike most dancers from countries with a well-established Highland dancing tradition (e.g., Scotland, Canada or Australia), I do not have a pair of practice swords at home, so I have to imagine these crossed over one another on the floor, creating squares ("spots") A, B, C and D labelled anticlockwise (SOBHD 2019: 30). The book says, "Bar 1: Pas de Basque into A with RF, then into D with LF". I read this and then mark two pas de basque steps with minimal elevation (and incorrect rhythm, I think) into spots A and D. Maybe I should have re-read the counting (" $1 \& 2, \underline{3 \&} 4$ ") before starting the move, but it is separated from the "text" of the step by the phrase "as in bar 1 of the fourth step".

"Bar 3: Open pas de Basque with RF in C", my right foot goes to spot C, "LF in D", my left foot goes to D on a half point, "in fourth opposite fifth position", I adjust the position of the left foot. I am not following the counting given next in the book, as I place the feet one after the other, not almost simultaneously as required in the actual dance.

... Having marked the rest of the step slowly and made sure I remember the sequence, I can now actually dance it more rhythmically over virtual swords. Practising to the music feels too early, because I need extra time to make sure my upper body turns are accurate enough and my foot positions are reasonably tight. I also need to add the arm movements as specified in the book: "First position in bar $1 ; 3^{\text {rd }}$ position in bars 2 and 3 ".

Moving on to the "older" step, one of those not included into the official competitive repertoire back in the 1950s-1960s but kept in the living memory of experienced dance teachers since then. Personally, I find this practice more interesting because virtually nobody performs these steps today.

"Bar 1 Pas de basque R in A...” Done, “...then Pas de Basque L in D.” Done.

"Bar 2 Pas de Basque R in B...” Done, “...then Pas de Basque L in C." Done. I can mark it as I read, because the instructions are short and quite clear. Right, what follows?

"Bar 3 Dance 4 High Cuts..." Probably without extensions as I am inside the swords? "... Springing R in B [done], then L in C [done] then Springing R in A [done] then L in D." Done. It would be quite a challenge to dance this over a pair of swords!

"Bar 4 Making $3 / 4$ turn R dance 2 Pas de Basque." Where??? OK, let me think. The step needs to proceed, so I should probably start the next quarter (the next four bars) springing from spot A to spot $\mathrm{B}$ on the first pas de basque with my right shoulder to the judge/the spectators. So bar 4 must be happening in spot A. Let me check... A three-quarter turn indeed! I probably need a quarter turn on the first pas de basque and half a turn on the following pas de basque. Let me dance the whole thing and see if it brings me to the initial position facing the spectators/the judge... It does!

$* * *$

I have not "bracketed" some of my personal preferences and specific circumstances from the accounts above to highlight the subjective nature of these accounts. Learner preferences and approaches can vary significantly, so their response to the same instructional texts will 
inevitably vary too.

However, it is clear that shorter instructions (including your own quick notes) can be easier to follow in real time as you read them unless they contain ambiguities. Longer, more descriptive "specifications" can be harder to digest, but they are more informative and provide explicit details, thus resolving potential questions. If I was a novice learner without prior knowledge of the RSOBHD book, I would have been unable to quickly solve the "mystery" of bar 4 of the "old" pas de basque step.

From a linguistic perspective, it is interesting to note that a dancer may treat "pas de basque to A" as a verb phrase directing their move, unlike "dance 2 pas de basque", where the term "pas de basque" is clearly used as a noun.

Highland dance teacher talk provides fewer contrasts in terms of being descriptive, prescriptive or instructive (directly calling for action), with a firm emphasis on the latter in the classroom. As a learner, I have mainly come across short, clear instructions, detailed personal feedback and focus on each dancer's improvement plus a strong emphasis on learning by imitation, with more experienced dancers (or younger teachers) demonstrating a lot, often without speaking, as in RSOBHD DVDs (e.g., SOBHD n/d).

As an SCD teacher and dancer, I will from time to time double-check what the RSCDS Manual (RSCDS 2011) says. However, together with 23 out of 36 SCD teachers from Scotland, England, Canada, the US, Australia, New Zealand, Germany, the Netherlands, Uruguay and Japan who responded to my questionnaire (Alferov 2019a), I feel that I am not very likely to consult the manual when it comes to teaching the pas de basque step. As a reasonably experienced SCD teacher from New York has put it, "I find that I have the characteristics and the points for teaching pas de basque in my head" (Alferov 2019a).

Nevertheless, 13 teachers from Australia (5), Scotland (4), Canada (2), the US (1) and Italy (1) responded that they do (or "would") consult the manual in and/or out of the class when it comes to the pas de basque technique. In addition, colleagues from Italy and Uruguay named the online SCD dictionary (Freemantle $\mathrm{n} / \mathrm{d}$ ) as a useful reference.

Both Freemantle (n/d) and RSCDS 2011 approach pas de basque as a step "used for" a range of functions (e.g., "setting", "turning" or "travelling") in a country dance, giving a very detailed account of the movements involved.

Despite some differences, e.g., a significantly more frequent use of present participles and a corresponding lower frequency of declarative present in Freemantle (n/d), the similarities between the two texts are apparent. Both Freemantle and the RSCDS manual use direct imperatives to instruct the reader in about $22 \%$ of their verb phrases, with around $10 \%$ allocated to deontic modal verbs expressing rules and prohibitions. The density of declarative verb phrases creates an impression that both sources describe the SCD pas de basque as it is, in an "objective" way, with the readers expected to accept things the way they are. Frequent use of the passive voice, especially following modal verbs may intensify this feeling and create a sense of excessive formality SCD has been criticised for (Alferov 2019b: 175).

Publications introducing simple and non-regulated social dance repertoire frequently labelled Ceilidh dancing are a much lighter read. Despite the fact that some Ceilidh dance callers helping at events such as weddings or social dance nights occasionally use the term "pas de bas(que)", quite often they mean the following: "Face your partner, kick right foot over your left and hop, then left foot over your right and hop" (Greig 2019). All verb phrases here are direct imperatives, which makes the instructions easy to follow. 
Table 2

Table 2 provides a summary of verb forms/patterns used in both sources

\begin{tabular}{|c|c|c|c|}
\hline Mode/modality & Example & $\begin{array}{l}\text { Number of } \\
\text { occurrences }\end{array}$ & $\begin{array}{l}\% \text { from all verb } \\
\text { phrases (excluding } \\
\text { gerunds) }\end{array}$ \\
\hline Imperative & $\begin{array}{l}\text { Take weight onto the left foot }(F) \\
\text { Begin the step with a spring }(R)\end{array}$ & $\begin{array}{l}19(\mathrm{~F}) \\
14(\mathrm{R})\end{array}$ & $\begin{array}{c}22 \%(\mathrm{~F}) \\
21.5 \%(\mathrm{R})\end{array}$ \\
\hline $\begin{array}{l}\text { Declarative present } \\
\text { (active voice) }\end{array}$ & $\begin{array}{l}\text { Whenever the opportunity arises } \\
\text { (F) } \\
\text { It follows, therefore... (R) }\end{array}$ & $\begin{array}{l}13(\mathrm{~F}) \\
17(\mathrm{R})\end{array}$ & $\begin{array}{l}15 \%(\mathrm{~F}) \\
26 \%(\mathrm{R})\end{array}$ \\
\hline $\begin{array}{l}\text { Declarative present } \\
\text { (passive voice) }\end{array}$ & $\begin{array}{l}\text { One foot is extended diagonally } \\
\qquad(\mathrm{F}) \\
\text { When two hands are given (R) }\end{array}$ & $\begin{array}{l}11(\mathrm{~F}) \\
10(\mathrm{R})\end{array}$ & $\begin{array}{c}12.9 \%(\mathrm{~F}) \\
15 \%(\mathrm{R})\end{array}$ \\
\hline $\begin{array}{l}\text { Deontic modals (cam, } \\
\text { must, may, should) }\end{array}$ & $\begin{array}{l}\text { The travelling can only be on the } \\
\text { first beat }(\mathrm{F}) \\
\text { Care must be taken }(\mathrm{R})\end{array}$ & $\begin{array}{l}9(\mathrm{~F}) \\
7(\mathrm{R})\end{array}$ & $\begin{array}{l}10.5 \%(\mathrm{~F}) \\
10.7 \%(\mathrm{R})\end{array}$ \\
\hline $\begin{array}{l}\text { Present participles } \\
\text { as part of non-finite } \\
\text { clauses }\end{array}$ & $\begin{array}{l}\text { While raising the left foot }(\mathrm{F}) \\
\text { Beginning with the left foot }(\mathrm{R})\end{array}$ & $\begin{array}{l}15(\mathrm{~F}) \\
6(\mathrm{R})\end{array}$ & $\begin{array}{c}17.6 \%(\mathrm{~F}) \\
9 \%(\mathrm{R})\end{array}$ \\
\hline $\begin{array}{l}\text { Past participles as part } \\
\text { of non-finite clauses }\end{array}$ & $\begin{array}{l}\text { If specified otherwise }(F) \\
\text { When danced on the balls of the } \\
\text { feet }(R)\end{array}$ & $\begin{array}{l}6(\mathrm{~F}) \\
4(\mathrm{R})\end{array}$ & $\begin{array}{l}7 \%(\mathrm{~F}) \\
6 \%(\mathrm{R})\end{array}$ \\
\hline
\end{tabular}

Some older Ceilidh dance books (Shepherd 1992, Ewart and Ewart 1996) retain the basic rhythm and some of the structure of the SCD pas de basque, encouraging readers to get acquainted with the step, not replace it with a kick and a hop. Both sets of instructions are relatively short. The proportion of imperatives is very high in Ewart and Ewart (1996): 5 out of 7 verb phrases (71.4\%). In Shepherd (1992), 4 out of 15 (26.6\%) verb phrases are in the imperative. This is partly because the latter aims to entertain and encourage prior to and alongside instructing: "We have danced blissfully over the years to pas de basque [...] A'body can paddybaa as we call it even on the disco floor" (Shepherd 1992: 21). "Paddybaa" is used as an action verb in its own right here, which seems to add to the informality of the tone, creating a sense of immediacy and interconnectedness between the language and the movement. The readers are invited to join in and participate, no matter how well they have "master[ed] the technique with both feet that inch above the floor" (Shepherd 1992: 21).

The distinction between imperative and declarative verbs in SCD (and Ceilidh) dance instructions is context-sensitive. On a page in a book or when a master of ceremonies (MC) "recaps" a Scottish country dance at a ball, i.e., reads/tells the dance description to remind all the dancers in the hall the formations they are about to perform, dancers read/ hear the following:

"First man sets to second woman and casts off one place" (RSCDS 1980: 7, Knight 2000: 120). "To set" in reel and jig time meaning "to dance two pas de basque", "sets" in such descriptions is clearly a declarative verb (present simple, third person singular) describing the dance. Below is a phenomenology-informed illustration aimed at highlighting, through 
"the dancing experience of the moving subject" (Warburton 2011: 76) how such texts can be perceived and interacted with at an SCD dance event.

$* * *$

The next dance on the ball programme is General Stuart's Reel published in RSCDS Book 10 (RSCDS 1935). I am going to dance it with a person I have not danced with today yet, which is common politeness in the SCD world.

As the band starts playing the tune (The Stuart's Rant), couples form longwise sets, with men (and some women) standing in lines with their left shoulder to the band and women in the line opposite (Picture 4). I am feeling quite confident, so we take the position of the first couple.

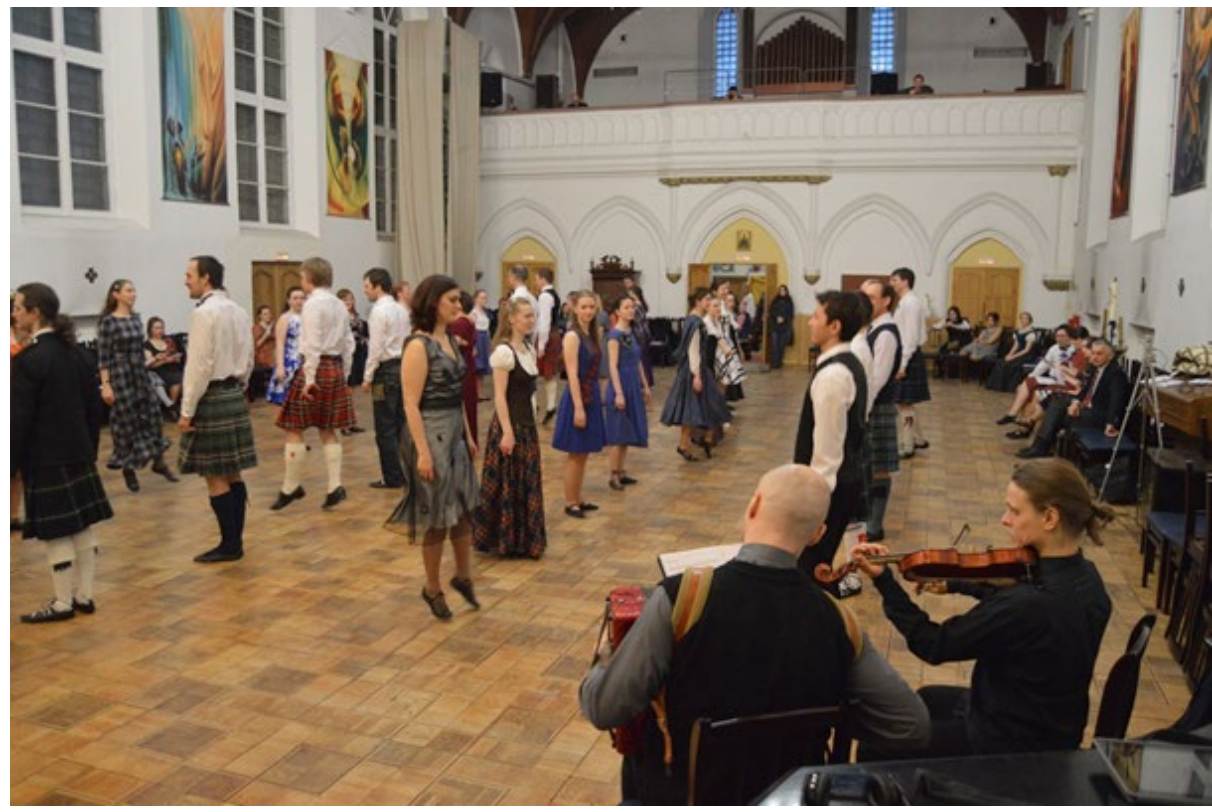

Pic. 4. Scottish country dancers in 4-couple sets at an SCD ball. St. Andrew's Anglican Church, Moscow, March 2015. Photo by P. Vatagina.

My partner and I having made sure our long set is divided into sets of four couples (eight dancers in each), we are ready to listen to the MC's recap. As I am the first man, I am trying to visualise what is about to happen from this dancer's perspective. "First man sets". OK, so when the dance starts after the full recap has been given, I will be starting with two pas de basque, probably pulling back my left shoulder slightly on the second one, to make the casting off that follows a bit smoother... "First woman sets to second man". I will be standing in second place at that point, so if necessary, I will be able to remind less experienced dancers (including my partner if she forgets something) that this is their time to "set" to each other.

Indeed when the dancing starts, I find myself occasionally saying: "Set!" either to the woman in the third place when I start a new turn of the dance from the second man's place or to the second man and my partner. As the dance goes on, my own identity changes: I stand as the fourth man, then dance as the third man twice, dance as the second man twice and stand in the first place when the last couple finishes the very last turn of the dance. 
At some point, someone may gently remind me: "Set!" or: "Step up!" if I get carried away by the music and the atmosphere, exchanging smiles with fellow dancers or just watching other people enjoying themselves and forget that it is my turn to dance.

$* * *$

As can be observed, the immediacy of the link between the words and the dance moves may change a dance description into a direct call for action. This is especially clear when more challenging dances are walked through during the recap. In this case, phrases like "second couple set and giving right hands, cross over to finish in third place" (RSCDS 1962: 39) give instructions immediately followed by the dancers. The standing couple (e.g., the fourth couple in a longwise set) still look at the whole dance as observers, so for them the dancing words sound more like a descriptive commentary referring to what is being done by other dancers.

This fluidity of imperative/declarative (and instructional/descriptive) dynamics works generally similarly in Ceilidh dancing. Some dance callers quickly remind how the dance goes before the music starts, some name and briefly explain the moves with dancers walking the dances through without music first and some in addition voice the moves over the music when necessary to help the less experienced participants.

Scottish step dance publications tend to follow a "dance notes" format, very briefly naming the moves. Table 3 compares the way bars 1-2 of the fourth step of a solo dance King of Sweden are described in Wallace (1995: 15) and RSCDS (2013: 43).

Table 3

\begin{tabular}{c|c}
\hline RSCDS 2013: 43 & Wallace 1995: 15 \\
\hline $\begin{array}{c}\text { 1-2 Balancé forward and back (RDF \& LDB } \\
\text { [right diagonally forward and left diagonally } \\
\text { backwards]) }\end{array}$ & $\begin{array}{c}\text { Bars 1-2 RF [right foot] pas de basque derriere } \\
\text { RDF (1 and 2) pas de basque LDB (3 and 4) }\end{array}$ \\
\hline \begin{tabular}{l} 
backwas \\
\hline
\end{tabular}
\end{tabular}

Both dance descriptions give their reader a brief account of what happens during the first two bars of the fourth step, with slightly different terminology used to refer to the same movement. It is up to the reader to interpret these notes either as a description of what the dance looks like or as a call for action.

With reference to Q2 above, the role of imperatives and other verb forms in Scottish dance instructions is far from straightforward. Ultimately, the changing context can significantly alter the role the same phrase plays in teaching and learning, up to a point where a noun phrase becomes a verb phrase and vice versa. The context-sensitive nature of the relationship between pedagogic discourse and dance teaching practice means that changing discursive features may not lead to significant and/or predictable changes in embodied practice. Language is a flexible and subtle tool, which informs, construes but does not fully determine what happens in a given situation (cf. Fairclough 2004: 230).

\section{Using the teacher's voice: promoting learner empowerment and/or docility?}

Given "the asymmetric authority inherent in the pedagogic relation" (Rose 2018: 8), traditional education has been labelled as an "essentially paternalistic project" (Ellsworth 
1989: 307). Non-improvisational styles of Scottish dancing may be seen as a clear example of traditional dance pedagogy that "emphasizes silent conformity in which dancers reproduce what they receive" (Kerr-Berry, Clemente and Risner 2008: 94).

Examining such concerns, multiple interpretations of the same discursive practice and/or social situation have to be taken into account in order to avoid forcing "certain ideological meaning" (Blommaert, Bulcaen 2000: 455) onto a piece of pedagogic discourse. To make sure my analysis remains as situated and contextualised as possible, I will consider the issue of dance learner empowerment as opposed to disciplined somatic "docility" by re-examining some of the "dancing words" used by Scottish dance teachers in various situations.

"Spring beat beat" (Knight 2000: 40, RSCDS 2011: 5.4.2) is a rhythmic formula frequently accompanying SCD and, possibly, Scottish (ladies') step dancing practice when marking the rhythm of the pas de basque, as seen on some instructional videos (Reznick 2012, Scot Step 2013b). In dance classroom contexts, "spring" as an imperative clearly manifests a "directive force", i.e., "an illocutionary act that provides a hearer with a [...] reason to act" (Jary, Kissine 2016: 6). This force is almost tangible in a video filmed in Portland (Oregon, US) by candidates wishing to obtain a full teaching qualification from the RSCDS (Reznick 2012).

Nine trainee SCD teachers are arranged in two rows and, accompanied by a pianist, present a 64-bar routine taking them from clapping to the music to performing a sequence of three-beat pas de basque steps. One of them is giving instructions as the sequence develops. After she commands: "Spring beat beat", the group starts adding a jump from one foot to the other to their sequence of movements.

Interestingly, the "caller" (as well as the other dancers) starts springing with more energy not on the first beat of the 49th bar when she first intones: "Spring beat beat", but on the following, 50th, bar. Although this is a pre-learnt sequence, and the dancers anticipate the change form a slightly "bouncy" ("lilting") step to a more active "spring", the transition seems to require some extra time. "Spring!" repeated eight times (the first six times followed by "beat beat") seems to boost the group's energy levels, motivating them to elevate and helping keep the movements rhythmical.

The setting may seem somewhat dystopian: we see obedient ("docile") dancers following commands delivered in quite an assertive manner (loudly enough that they are heard above the live piano music) and trying to conform to a predetermined standard set by a worldwide organisation, the RSCDS. The tone of the voice-over sounds very straightforward and "pushy", contrasting sharply with the gently flowing notes of the reel played with elegance and ease. As a dancer, I am instantly reminded of the fact that a lot of SCD practice worldwide is done in school gyms.

However, in terms of power relations, the situation may not be that straightforward. The voiceover comes from one of the dancers, who is part of the group, not separated in terms of space (she is one of the four dancers in the front row) or function (she is dancing together with everybody, and her dancing gets momentum as she speaks). The language of instruction thus facilitates dancing as a (friendly) reminder and an extra source of drive: "spring" may be meant to empower dancers, without necessarily dominating or oppressing them even as it restricts the dancers' choice of movement to the only option for this particular moment.

Thus, the discursive practice of dance teaching remains open to multiple contrasting interpretations, even when contextualised and analysed multimodally, with prosodic features, visual and paralinguistic auditory cues taken into account. 
Jump! Whereas the RSOBHD Highland dancing textbook explicitly highlights the difference between a hop, spring, assemble and disassemble as movements of elevation (SOBHD 2018: 13-14), the RSCDS manual does not go into that much detail. Until 2011, "jump beat beat" was provided alongside "spring beat beat" as counting for pas de basque (RSCDS 1997: 5.4).

Although "jumping" as a concept is less precise, it may be more accessible for learners, especially younger ones.

For instance, at the "Kids in Kilts" school in Winnipeg, Manitoba, Canada, they say: "Jump (over the puddle) - climb the tree". In the video "created to help my younger dancers practise basic Highland dance movements at home" (Kids in Kilts 2013), the teacher, Zoë Wreggitt, varies the pattern of her instruction by combining imperatives ("point your toe", "step over the puddle", "jump - climb the tree") with a modal expressing possibility/ permission ("After that you can add a jump") and a declarative sentence to describe the procedure ("And after that you just jump over the puddle").

The tone of the teacher is light and conversational, although she dances and speaks at the same time. Using imperatives helps keep things simple by providing clear instructions that correspond directly to what is being danced and motivate dancers to reach further in their pas de basque by jumping "over the puddle", not into it.

"Jump beat beat" is also used by a high-profile RSCDS teacher from Scotland Moira Stacey in her Youtube video dedicated to the pas de basque step (Stacey 2015). She introduces this as follows:

To move on to the next stage of [learning] the step, Keith is going to add in a little jump. With me, Keith, as I say it. Ready and... Jump beat beat, jump beat beat, jump beat beat, jump beat beat. Thank you, Keith.

As the teacher is speaking, Stacey's husband Keith jumps along as instructed. So should the online viewers, as indicated earlier in the video. Compared to the "Kids in Kilts" video, the discourse of instruction here limits the dancer's choices in a number of different ways. Where Wreggitt explicitly engages the viewer by dancing herself and presenting a jump as an opportunity for the viewer ("you can add"), Stacey uses an intermediary "demonstration" dancer presenting his intentions herself ("Keith is going to add"). Keith keeps silent and obediently does as the teacher says as (when) she says it. The standard RSCDS rhythmical formula "ready and..." informs the dancer when to start jumping regardless of whether (s)he is in fact ready or not.

The other way to look at this contrast would be to argue that Wreggitt relies on her viewers' being familiar with the dance movement they can practise whereas Stacey makes a lot of basic information accessible to an inexperienced dancer. Stacey sees her viewers as requiring careful step-by-step guidance to do everything "correctly" whereas Wreggitt just provides them with an opportunity to practise as they dance along. Given the fact that Highland pas de basque is physically and technically more demanding than the SCD one, it would be inadvisable for complete beginners to try to imitate the "Kids in Kilts" teacher.

Being more explicit thus may entail sounding "bossy" but at the same time it allows to share more with the learner, making the instructions clearer (Daly and Vangelisti 2003: 887) and the knowledge more widely accessible. Letting the dancers "jump along", on the other hand, can mainly benefit those already "in the know", keeping the knowledge restricted to a narrower community of practitioners. 
Thus, it can be argued that a more "authoritarian" style of teaching seeks more procedural control on the part of a teacher but potentially allows easier and wider learner access to knowledge. A practical implication here would be for dance teachers to be able to vary their degree of control responding to the current learners' needs and priorities ( $c f$. Nunan 2004: 35) providing clear guidance without excessively restricting the learners. From a discourse analyst's perspective, a careful examination of jumping in the pas de basque can serve as a contextualised reminder to avoid jumping to conclusions when interpreting discursive practices.

(Together) beat! When teaching the two-beat pas de basque used in the Sword dance, Highland dance teachers frequently repeat the formula: "together beat" (BBC 1996a). "Together" rhythmically signals what to do during the counts " $1 \&$ " when feet land almost (but not quite) simultaneously in 3rd position, while "beat" reminds the dancers to "beat (without exaggeration) the ball of the other foot in third or fifth rear position, at the same time sharply extending the front foot if required" (SOBHD 2008: 22).

When used repeatedly, with a pronounced directive force and loudly enough to be heard over bagpipe music, the "together beat" formula may be seen as an indicator of the need to "keep pushing and pushing and pushing them", as Linda Napier, one of the top Highland dance teachers from Scotland, put it (BBC 1996b).

When pushing a dance student to reach the maximum of their own potential and make their footwork impress judges at Highland dance competitions, dance teachers restrict the learners' choices and free will at the same time investing a lot of energy and attention in the learners' progress. This investment as well as these restrictions are clearly audible in "together beat!"

As dance technique is defined by the RSOBHD and assessed by RSOBHD-certified judges at competitions, the teacher and the learner work hard together to comply with the externally set rules and preferences. Whatever the teacher-learner power imbalance may be in a given classroom, for ambitious competitive dancers most power remains with the judge and the rules this judge adheres to.

The need to look beyond a dance classroom or indeed any given communicative exchange to clearly see the power dynamics as referred to in Q3 above highlights the role of discourse in signalling but not necessarily determining power relations in a range of social situations. The subtleties of power relations in a given dance classroom, although expressed in the dance discourse, may vary considerably and therefore have to be examined very carefully, even in seemingly straightforward situations, to avoid an oversimplified vision of teaching approaches as giving "power to the teacher to manipulate students' bodies" (Green 2002-03: 100). Even when "imposing operational laws of movement" (Franko 2019: 82), a teacher can either facilitate or hinder the development of a student's body as a medium of artistic and/or social expression (cf. Franko 2019: 91).

\section{"The words are often nonsense": conclusion}

The range of discursive practices within the Scottish dance tradition(s) examined in this article helps appreciate how intricately language and movement are intertwined in teaching and learning the dance repertoire(s) of Scotland.

Analysing the discursive practices of Highland, SCD and Scottish step dance teachers alongside Ceilidh dance callers allows to see noticeable differences between 
these styles in linking dance and musicality, rhythm and technique, rules and variation, work and enjoyment.

Focusing on verb phrases in various dancing situations may deepen our understanding of how dance instructions and dance descriptions engage learners, how accessible they are and to what extent they call for immediate action. However, the directive force of verb phrases and even their grammar (e.g., imperative versus declarative mode) can vary significantly depending on a given situation and a particular listener's role (e.g., the dancing or the standing couple in SCD).

Given such fluidity of meaning and function in dance discourse, it is hardly surprising that the power dynamics in Scottish dance classes is open to multiple interpretations. Although it remains important to acknowledge that pedagogic discourse is very seldom, if ever, "neutral" (Christie 2002: 7), a word of caution must be made against oversimplifying somatic "docility" based on a generalised interpretation of dance-related discourse. It seems that a balance is needed between a researcher's "rich exposure to a communicative tradition", a deep and reflective "immersion in social networks" (Levinson 2003: 29) and an ability to take a critical stance and raise awareness of the potentially oppressive discursive patterns when those are (over)used by dance practitioners or, indeed, researchers themselves.

\section{Primary sources}

Alferov, S. 2019a. Teaching pas de basque: SCD, Highland and Scottish step dancing: A questionnaire. https://forms.gle/6DKCzH8xXNPpiKH5A Accessed on 07 November 2020.

BBC. 1996a. That Fling thing [“Together Beat"]. https://youtu.be/B-bFD6Imti0?t=221. Accessed on 07 November 2020.

BBC. 1996b. That Fling thing. https://youtu.be/B-bFD6Imti0?t=1263. Accessed on 07 November 2020.

Cowing, B. 2019. Britannia Two Step at Fortingall Village Hall Christmas Ceilidh. https://youtu.be/ pDE5x8noGfE. Accessed on 07 November 2020.

Cutting Edge Band. 2017. Wedding Dashing White Sergeant. https://youtu.be/GLCKIlSMG9w. Accessed on 07 November 2020.

Donald, D. 2010. SCD technique: pas de basque/setting step. https://youtu.be/6s2QiF1JdIw. Accessed on 07 November 2020.

Freemantle, $R$. N/d. Pas de basque. https://www.scottish-country-dancing-dictionary.com/pas-debasque.html. Accessed on 07 November 2020.

Kids in Kilts. 2013. Pas de basque. https://youtu.be/IpDvuEPz8r4. Accessed on 07 November 2020.

Knight, P., ed. 2000. Collins Scottish country dancing. Compiled in association with the Royal Scottish Country Dance Society. Glasgow: HarperCollins Publishers.

MacLennan, D. G. 1952. Highland and traditional Scottish dances. Edinburgh: T \& A Constable.

Milligan, J.C., and D.G. MacLennan. 1950. Dances of Scotland. London: Max Parrish and Company.

Milligan, J.C. 1956. Won't you join the dance? Manual of Scottish country dancing. London: Paterson's Publications.

NWSD. 2005. The New World Scottish dancers collection. Vol. 1: Scottish step dances. San Francisco: New World Scottish Dancers.

Perreault, L. 2020. Sword Dance last step: Quick time for beginners and up! https://youtu.be/sD9LAYgkYqQ. Accessed on 07 November 2020.

Reznick, G. 2012. Zero to pas de basque in 64 bars. https://youtu.be/sbhTkZuJhXc. Accessed on 07 November 2020.

RSCDS. 1962. The Pocket edition Scottish country dance books XIX, XX and XXI. Edinburgh: The Royal Scottish Country Dance Society.

RSCDS. (1939) 1980. The Pocket edition Scottish country dance books X, XI and XII. Edinburgh: The Royal Scottish Country Dance Society. 
RSCDS. 1997. The Manual of Scottish country dancing. Edinburgh: The Royal Scottish Country Dance Society.

RSCDS. 1999. Reel Scottish dancing. https://youtu.be/iF-QZqMxb20?t=338. Accessed on 07 November 2020.

RSCDS. 2011. The Manual of Scottish country dancing. Electronic version with updates. Edinburgh: The Royal Scottish Country Dance Society.

RSCDS. 2013. The St. Andrew's collection of step dances. 2nd ed. Vol. 1: The dance descriptions, Revised 2013. Edinburgh: The Royal Scottish Country Dance Society.

RSCDS. 2019. Steps and holds. https://www.rscds.org/learn/steps-techniques/steps-holds. Accessed on 07 November 2020.

RSCDS Edinburgh. 2020. Bitesize at home classes - Pas de basque. https://youtu.be/eEP1bpef7FI. Accessed on 07 November 2020.

SCD Teachers. 2020. Scottish country dance teachers. Public Group https://www.facebook.com/ groups/5808618015/permalink/10157343605968016/. Accessed on 07 November 2020.

Scot Step. 2013a. First position. https://youtu.be/8mnjq99avcg. Accessed on 07 November 2020.

Scot Step. 2013b. Pas de basque. https://youtu.be/ZSFsRlb3QR4. Accessed on 07 November 2020.

Scot Step. 2019. Dance teacher's voice: Helen Russell. https://youtu.be/t6lNHaetTh4. Accessed on 07 November 2020.

Scot Step. 2020. Jo's Delight (step 2 out of 4): Scottish step dance tutorial with Diana Hastie. https://youtu.be/gXjmnORscHE. Accessed on 07 November 2020.

Scott, N. 2014 Scottish country dancing - Pas de basque step. https://youtu.be/_tj6iXEpQyk

SOBHD. N/d. Highland Dancing. $8^{\text {th }}$ Edition DVD.

SOBHD. 1968. Highland dancing: the official textbook of the Scottish Official Board of Highland Dancing. New and revised edition. London and Edinburgh: Thomas Nelson.

SOBHD. (1996) 2008. Highland dancing: the textbook of the Scottish Official Board of Highland Dancing. 7th ed. Glasgow: Lindsay Publications.

Stacey, M. 2015. Tutorial 1 of Moira Stacey's Scottish dancing - Pas de basque. https://youtu. be/7SINR-UCIYE. Accessed on 07 November 2020.

\section{References}

Alferov, S. 2019b. "Estestvennost"” v shotlandskom tantse s pozitsii etnolingvistiki ["Naturalness" in Scottish dancing: An ethnolinguistic perspective]. Vestnik Antropologii 47 (3): 169-188. DOI: 10.33876/2311-0546/2019-47-3/169-188.

Bernstein, B. 1990. The Structuring of pedagogic discourse. Vol. IV: class, codes and control. London and New York: Routledge.

Blommaert, J., and C. Bulcaen. 2000. Critical discourse analysis. Annual Review of Anthropology 29: 447-466.

Cameron, D., and I. Panović. 2014. Working with the written discourse. Los Angeles, London and New Dehli: Sage.

Christie, F. 2002. Classroom discourse analysis: a functional perspective. London and New York: Continuum.

Daly, J.A., and A.L. Vangelisti. 2003. Skillfully instructing learners: How communicators effectively convey messages. In Handbook of communication and social interaction skills, edited by J.O. Greene and B.R. Burleson. Manwah and London: Lawrence Erlbaum Associates. 871-908.

Ellsworth, E. 1989. Why doesn't this feel empowering? Working through the repressive myths of critical pedagogy. Harvard Educational Review 59 (3): 297-324.

Fairclough, N. 2004. Semiotic aspects of social transformation and learning. In An Introduction to critical discourse analysis in education, edited by R. Rogers. Mahwah, New Jersey and London: Lawrence Erlbaum Associates, 223-235. DOI: 10.1075/z.184.77fai 
Foucault, M. (1982) 1994. Le sujet et le pouvoir. In Foucault M. Dits et écrits IV, 222-243. Paris: Gallimard.

Franko, M. 2019. Archaeological choreographic practices: Foucault and Forsythe. In Choreographing discourses: A Mark Franko reader, edited by M. Franko with A. Nicifero, 81-95. London and New York: Routledge.

Green, J. 2002-03. Foucault and the training of docile bodies in dance education. Arts and Learning 19 (1): 99-126.

Havis, D.N. 2014. Discipline. In The Cambridge Foucault lexicon, edited by L. Lawlord and J. Nale, 110-119. Cambridge: Cambridge University Press.

Jary M, and M. Kissine. 2016. When terminology matters: The imperative as a comparative concept. Linguistics 54 (1): 119-148. DOI: 10.1515/ling-2015-0039.

Keevallik, L. 2013. Decomposing movement: Spatial deixis in dance instruction. In Interaction and Mobility: Language and the Body in Motion, edited by P. Haddington, L. Mondada, and M. Nevile, 347-372. Berlin and Boston: DeGruyter.

Keevallik, L. 2015. Coordinating the temporalities of talk and dance. In Temporality in Interaction, edited by A. Deppermann and S. Günthner, 309-336. Amsterdam: John Benjamins Publishing. DOI: $10.1075 /$ slsi.27.10kee.

Kerr-Berry, J., K. Clemente, andD. Risner. 2008. ThePolitics of personal pedagogy: Examining teacher identities. Journal of Dance Education 8 (3): 94-101. DOI: 10.1080/15290824.2008.10387363.

Van Leeuwen, T. 2008. Discourse and practice: New tools for critical discourse analysis. Oxford: Oxford University Press.

Levinson, S.C. 2003. Contextualising contextualisation cues. Retrieved from http://vm136.lib. berkeley.edu/ANTH/emeritus/gumperz/gumpb.pdf on 21 October 2020.

Melin, M. 2018. A Story to every dance: The Role of Lore in Enhancing the Scottish Solo Dance Tradition. Lorg Press.

Nunan, D. 2004. Task-based language teaching. Cambridge: Cambridge University Press.

Pakes, A. 2011. Phenomenology and dance: Husserlian meditations. Dance Research Journal 43 (2): 33-49. DOI: 10.1017/S0149767711000040.

Roach, P. 2009. English phonetics and phonology: A Practical course. Cambridge: Cambridge University Press.

Rose, D. Pedagogic register analysis: Mapping choices in teaching and learning. Functional Linguistics 5 (3): 1-33. DOI: 10.1186/s40554-018-0053-0/

Shernoff, D.J., and M. Csikszentmihalyi. 2009. Flow in schools. In Handbook of positive psychology in schools, edited by R. Gilman, E. S. Huebner, and M.J. Furlong, 131-146. London: Routledge.

Smith, D.W. 2012. Perception, context, and direct realism. In The Oxford handbook of contemporary phenomenology, edited by D. Zahavi, 134-157. Oxford: Oxford University Press.

Spry, T. 2001. Performing autoethnography: An embodied methodological praxis. Qualitative Inquiry 7 (6): 706-732. DOI: 10.1177/107780040100700605/

Underhill, A. 2005. Sound Foundations: Learning and Teaching Pronunciation. Oxford: Macmillan.

Warburton, E. 2011. Of Meanings and Movements: Re-Languaging Embodiment in Dance Phenomenology and Cognition. Dance Research Journal 43 (2): 65-84. DOI: 10.1017/ S0149767711000064/ 
Алферов Сергей Владимирович

\section{ОТ СЛОВА К ДВИЖЕНИЮ: ДИСКУРСИВНЫЕ ПРАКТИКИ ПРЕПОДАВАНИЯ ШОТЛАНДСКОГО ТАНЦА}

DOI: $10.33876 / 2311-0546 / 2021-54-2 / 177-197$

Статья совмещает методы танцевальной антропологии и мультимодального дискурс-анализа, фокусируясь на использовании английского языка для преподавания и описания различных версий па де баска - танцевального шага, характерного для различных стилей шотландского тания (Highland, Scottish country, Scottish step, Ceilidh dancing). В статье анализируется педагогический дискурс онлайн и оффлайн классов и других событий в разных регионах мира, а также собственный танцевальный опыт автора как танцора, ученика и преподавателя шотландского танца. Рассматривая использование английского языка в преподавании шотландского танца в различных культурных и соматических контекстах, статья анализирует учебные материаль и описания танцев, опубликованные между 1950 г. и 2020 г. такими организациями, как Королевское общество шотландских танцев (RSCDS), Королевский официальный совет по танщам хайланд (SOBHD), Британский альянс профессиональных преподавателей танца (UKA), а также индивидуальными авторами. Обращаясь $\kappa$ вопросам коммуникации статуса и делегирования полномочий в классе, роли дискурсивных практик в переосмыслении, изменении и (де)регуляции танцевальных традиций, исследование помогает лучше понять взаимосвязь и взаимозависимость педагогического дискурса и разнообразных сочиокультурных практик, связанных с обучением традиционному таниу и его преподаванием.

Ключевые слова: педагогический дискурс, обучение таниу, властные отношения в классе, традиционныйтанец, шотландскийтанеи, этнолингвистика, этнохореология, танцевальная феноменология

Ссылка при цитировании: Алферов С.В. От слова к движению: дискурсивные практики преподавания шотландского танца // Вестник антропологии, 2021. № 2. C. 177-197.

Об авторе: Алферов Сергей Владимирович - руководитель Школы шотландского и валлийского танца Shady Glen. Эл. почта: scotstepdance@gmail.com. 